\title{
Article \\ Experiences and Perceptions of Young Adults with Physical Disabilities on Sports
}

\author{
Kim Wickman \\ Department of Education, Umeå University, 90187 Umeå, Sweden; E-Mail: kim.wickman@umu.se
}

Submitted: 12 August 2014 | In Revised Form: 2 November 2014 | Accepted: 14 January 2015 |

Published: 25 June 2015

\begin{abstract}
People with disabilities seldom get a chance to voice their opinions on their sport experiences. A deeper understanding of the context-related experiences of sport is a prerequisite for teachers and leaders to be able to provide adequate, inclusive and meaningful activities. The aim of this qualitative case study was to examine how young people with disabilities made sense of sport, within both the compulsory school system and the voluntary sports movement. The study involved 10 young adults (aged 16 to 29 years) with disabilities, five males and five females. All the participants had rich experiences of sport. An inductive approach to qualitative content analysis of semi-structured interviews was used to enable individuals to explain and give meaning to their experiences of sport including those pertaining to gender and inclusion. The findings illustrated that dominating gender and ability norms influenced the interviewees' understanding of themselves in relation to sport; as a consequence, some of the female interviewees had a more diverse, sometimes contradictory experience of sport than the male interviewees. The basic premise of this study is that researchers can develop more insightful understandings of inclusion by studying the subjective meanings that are constructed by people with disabilities in their sport experiences.
\end{abstract}

\section{Keywords}

diversity; physical education and health; social inclusion; sporting bodies

\section{Issue}

This article is part of the special issue "Sport for Social Inclusion: Critical Analyses and Future Challenges", edited by Dr. Reinhard Haudenhuyse (Vrije Universiteit Brussel, Belgium) and Professor Marc Theeboom (Vrije Universiteit Brussel, Belgium)

(C) 2015 by the author; licensee Cogitatio (Lisbon, Portugal). This article is licensed under a Creative Commons Attribution 4.0 International License (CC BY).

\section{Introduction}

Swedish and international research on children and young people with disabilities in sport activities has, until recently, been more or less a non-issue (Smith \& Thomas, 2006). While some research has examined teachers' experiences of Physical Education and Health $(\mathrm{PEH})$, a gap exists in the literature about the experiences of children and young people with disabilities involved in sport activities (c.f., Fitzgerald, Jobling, \& Kirk, 2003; Smith \& Thomas, 2006). For many children and young people, sport forms a significant part of their lives, shaping their development into members of society and the sorts of people they become. Through sport as a social activity, they can learn to establish and keep friendships, negotiate with others, solve conflicts and develop leadership qualities and self-confidence (Özdemir \& Stattin, 2012). However, studies have suggested that children and young people with disabilities tend to be excluded from sport (Kristén, Patriksson, \& Fridlund, 2002; Smith \& Thomas, 2006; Vickerman, Hayes, \& Whetherly, 2003). For example, Vickerman et al. (2003) found that few activities are inclusive and that children and young people with disabilities are only to a limited extent offered opportunities for full participation in sport in comparison with non-disabled people of the same age. The authors also discovered that withdrawals are more frequent among this popu- 
lation. In addition, they have generally fewer opportunities to participate due to physical, social and emotional barriers. Their experiences are often limited due to the lack of necessary skills, overprotective adults, social isolation, time-consuming treatment and care, and difficulties in getting to and from training and matches (Taub \& Greer, 2000). Additionally, previous studies have shown that mobbing and isolation, inaccessible premises, lack of sports aids and few individually adapted activities contribute to negative experiences and exclusion (Coates \& Vickerman, 2010). Crushed self-confidence is quite frequently a result of discrimination (Blinde \& McCallister, 1998; Goodwin \& Watkinson, 2000).

Research conducted with a focus on lived experiences has shown that children and young people with disabilities have positive experiences of sport in contexts where they are fully included and can develop their physical, mental and social skills (Goodwin \& Watkinson, 2000). However, very little research has attempted to define inclusive activities from an individual participation perspective (Maxwell \& Granlund, 2011; Smith \& Tomas, 2006). This is in particular true of children with complex needs and difficulties in communicating in speech and writing (Fitzgerald et al., 2003). Based on that argument, it is problematic that children and young people seldom have a chance to voice their opinions and hence have limited influence on their sports activities. Such a pattern of systematic invisibility may be explained as a form of "hidden discrimination", a concept that often arises in studies of gender equality (c.f., Husu, 2005). Hidden discrimination implies that children and young people in general, and those with disabilities in particular, are ignored or are not offered the support they need in order to develop, express their views and be considered in contexts that affect them. Hidden discrimination may also imply that nothing happens or that something that ought to happen does not occur, e.g. that individuals are not seen, heard, invited, asked, acknowledged or encouraged to participate in a sports context. Similarly, associations that formally represent children and young people with disabilities may not be given opportunities to express their opinions on issues or decisions that directly or indirectly affect the target group that they represent.

The aim of this study was to examine how young people with disabilities made sense of sport, within both the compulsory school system and the voluntary sports movement. The following research questions are posed:

- What is the meaning of sport according to the interviewees' experiences?

- Within the operating norms, how can sport be understood with the main focus on gender and ability?

By examining how young people with disabilities made sense of sport, within both the compulsory school system and the voluntary sports movement, this study contributes to a greater understanding of the role that sport can play in the personal and social growth of children and young people. It also highlights how different notions and expectations of inclusion, diversity, sporting bodies and gender operates in sport. The paper is structured as follows. First, I will outline some conceptual ideas. Then, I present the theoretical considerations and methodology applied in this study. Finally, I discuss the impact of gender and ability norms on the perceptions of sport for young adults with disabilities in accordance with the results of the study.

\section{Roles of Sports}

Over the past 20 years, the inclusion of students in need of special support in mainstream educational settings has increased in many countries (Fitzgerald, 2005; Smith \& Thomas, 2006). Though "inclusion" is a political term more frequently used in the compulsory school system (Maxwell \& Granlund, 2011; Nilholm, 2006). It is not at all a foreign concept in the Swedish sport movement. In fact, the Swedish sport movement adheres to the UN's Universal Declaration of Human Rights, the UN Convention on the Rights of the Child and the Convention on the Rights of Persons with Disabilities (Wickman, 2011a). The policy programme for Swedish sport, entitled "Sport wills-aims and guidelines for the sports movement", represents a common system of values for the entire sport movement and provides guidelines for the organisation of sport activities in federations and clubs (Riksidrottsförbundet, 2009). Human rights have generally developed into a central subject, and sports and human rights are essentially tied to each other, at least ideologically. Sport is considered as a tool for reducing discrimination, for strengthening youth, and for promoting peace, tolerance and friendship. Furthermore, sports provide individuals with health, recreation and rehabilitation. The Swedish sports movement's policy documents state that sport for children and young people must be conducted from a children's rights perspective and follow the UN's child convention (Unicef, 2008). However, sport has been known to neglect human rights, despite the ideological foundation of sport in equality and fairness (Carlsson \& Fransson, 2005). Trondman (2011) described this situation as a sports policy dilemma. He argues that even if it is desirable, it is difficult to steer sports activities towards democracy with the young people's participation, as the sport's internal core logic primarily is about other things, such as training, competition and achievements, based on notions and expectations of what "real sport" is and should be about. This limits the ability to include, for instance sports for disabled and individuals with disabilities since they do not unconditionally meet such expectations. 


\section{Sporting and Gendered Bodies}

Children develop early an awareness of what bodies are regarded as accepted and desired, which has consequences for how they conceive of and understand themselves and each other in relation to sport. As Evans, Rich, Allwood and Davies (2007) have argued, distinctions between "able" and "non-able" participants can be seen to relate to specific social and political meanings in and around sport, gender and young people's participation, which circulate through a range of dominating notions and understandings of what "real sport" is and should be about (Wickman, 2008, 2011b). Such distinctions are important since they relate to the allocation of resources as well as according value to specific bodies (Clark, 2012). Dominating notions and understandings of "being good at sport" might therefore be seen as representing particular ideals of sporting participation and as containing particular signifiers about who might embody such an identity and what physical performances this requires. Consequently, sporting participation requires both an affective investment, as a sense of "fit" with dominant ideas of athleticism, and an embodied sense of capacity, as a set of skills and competencies gained through participation and practice over time (Clark, 2012; Shilling, 2004). According to Redelius, Fagrell and Larsson (2009) what is regarded as a capable, functional and achieving body is also evident in the teachers' marking where boys with experience of organised sport are favoured and girls' interests are ignored in the planning of the teaching. PEH is a popular school subject, and the majority of students have positive experiences of participation (Karlefors, 2012; Larsson, 2004). Although the compulsory school system and the voluntary sports movement have different goals for their sports activities, it is unclear where the dividing line lies between them (Peterson, 2005). Many teachers have been or are active as leaders in the sports movement in their leisure-time, and many have also competed in sports. This probably contributes to organised sport's norms, values and ideals having an impact on the PEH lessons in schools (Olofsson, 2007). The sports activities of schools may hence be said to be strongly influenced by the logic of competitive sport (Olofsson, 2007). For this reason, it is important that children and young people with disabilities be given access to sport, not only because this implies that the norm of capability is challenged through a widened representation of bodies capable of performing sport, but also because sport is one of the few institutions in society where people with disabilities can change their bodies from earlier characterisations as "defective" and "pathological" to signalling precisely empowerment and capability (Hargreaves, 2000).

Even though sports have the potential to encourage and enable both men and women to experience their bodies as powerful, autonomous instruments, women are allowed to be athletic only if they also engage in bodily practices to maintain their feminine image. For example, there are studies suggesting that women's contemporary involvement in sport and exercise is often accompanied by expectations of creating particular kinds of slim "fashionable dressed for success bodies" (Cole 1994, p. 16). In a similar way since the late 1980s, the multifaceted interaction of masculinities, gender and sport has been investigated by several researchers. Summarizing the findings of many of these studies, Rowe (1998) concluded that "sport has been an integral element of self-sustainable forms of exclusivist male culture, lubricating a closed system of male bonding and female denigration" (p. 246). These exclusivist practices have always been evident in sports for people with disabilities, who have been excluded from mainstream sport in various ways and to different degrees. As DePauw (1997) pointed out:

Historically, disabled people were excluded from sport given their "inability" to meet the socially constructed ideals of physicality, masculinity and sexuality. Those disabled individuals who were initially to some extent "included" were those who seemed the closest to the ideals, usually the White male with lower spinal cord injuries who competed in wheelchairs (p. 421).

Current research shows that sport and PEH still embody masculine ideals of physical strength and domination. This allows (some) disabled men the opportunity to exhibit key characteristics associated with the ablebodied concepts of masculinity, such as competitiveness, endurance and proper control of the body (Huang \& Brittain, 2006; Schell \& Rodriguez, 2001), thereby confirming their masculinity which might otherwise have been brought into question by their disability. Likewise, disabled men seek to demonstrate "physical prowess" through their sport participation (Huang \& Brittain, 2006). According to Messner (1992), given that "winning has been premised on physical power, strength, discipline, and willingness to take, ignore, or deaden pain", elite male athletes have a tendency to "experience their bodies as machines and as instruments of 'power' and 'domination'” (p. 151). Sport provides an interesting case to study in terms of diversity as there is a tension between performance (winning) and participation (recreation). Sports clubs contest competitions with the goal of winning which can work against the inclusion of people with diverse backgrounds and abilities (Spaaij et al., 2014).

Consequently, this paper builds on earlier studies which have shown the importance of gender and ability norms that are culturally and socially constructed to support dominant heterosexual masculinities (Butler, 1990; Oakley, 1972) and notions of the non-disabled body as the ideal body (Garland-Thomson, 1997; Sey- 
mour, 1998). This means that both gender and ability norms are constructed of masculine values such as strength, discipline, dominance and perseverance, which set the tone for how to conceive of and understand what "real sport" is and should be about (c.f., Schell \& Rodriguez, 2001; Wickman 2008, 2011a, 2011b).

\section{Methodology}

Qualitative researchers explore human phenomena in natural social settings and seek to grasp the meaning individuals make of their life experiences (Denzin \& Lincoln, 2008). An inductive qualitative design was used with a case study approach. According to Patton (2002) it permits the researcher to study selected issues in depth and detail and offer an understanding and insight into real, local meaning and experience of young adults with disabilities.

\section{Data Collection}

I decided to conduct semi-structured interviews because the intention of this study was to understand sport from the subjects' point of view and to uncover their lived world experiences (Kvale \& Brinkmann, 2009). The semistructured interviews were organised around a set of topics (i.e., background, the subjects' family and social life and their experiences of sport) formulated in an interview guide that was flexible enough to allow participants to develop the conversation in ways that were salient to them. As such, these interviews resulted in a range of expressions (e.g., notions, emotions, opinions, experiences and stories) that were amenable to analysis. I developed a semi-structured interview guide from the existing literature to retain a core of standardized questions and to ensure that the same basic themes were illuminated with each person interviewed. However, the interview guide remained flexible to allow for the exploration of participant experiences and any new issues that arose (Patton, 2002). Each respondent was interviewed individually in 55-110 minutes. In order to develop a thorough understanding of the case, a case study approach usually involves the collection of multiple sources of evidence, most commonly qualitative (and quantitative) techniques. The use of data triangulation has been advocated as a way of increasing the internal validity of a study (Patton, 2002). Due to the time restrictions a decision was taken to avoid the temptation to collect as much data as possible and instead prioritise adequate time to data analysis and interpretation of the qualitative interviews which offered a rich source of information. The reliability, validity and overall rigour of the analysis were strengthened by two fellow researchers independently reviewing the data followed by individual decisions and agreements on key themes. That I have just used one data source, limits this study concerning the validation of its results.

\subsection{Participants}

A purposeful snowball sampling strategy was utilized to recruit participants. Initially, I made contact with the permanent secretary of a local disability sport club to discuss how to get in contact with young men and women with disabilities. In order to delimit the study, participants with physical impairments (wheelchair users) were selected. Then I sent an introductory email to a disability sport club member email list inviting participation and asking individuals to identify other individuals to extend the scope of participants. This recruited a range of young people with physical impairments who had great experiences of sport from both the compulsory school system and the voluntary sports movement. All in all, 10 participants were selected through snowball sampling, a method that involves using networks to identify the sample (Ritchie \& Lewis, 2003).

Snowball sampling methodology (SSM) is a technique for finding research subjects where one subject gives the researcher the name of another, who in turn provides the name of a third, and so forth (Cohen \& Arieli, 2011). In this method, the sample group grows like a rolling snowball. Since the intention with this study was to seek interviewees from a small research population with specific characteristics, which were recognized by the population's individuals, SSM was an invaluable option. Notwithstanding these significant advantages, SSM has some distinct limitations. SSM is sometimes referred to as a "second best" methodology. A common claim is that is results in problems with representativity since it is not random; as a result, some researchers have noted that most snowball samples are biased and cannot be generalized (Kaplan, Korf, \& Sterk, 1987). Despite this significant limitation, Cohen and Arieli (2011) claimed that it is possible to increase the representativity of SSM by sufficient planning of the sampling process and goals, initiating parallel snowball networks and using quota sampling. In the present study, careful planning of the selection process occurred in relation to the study's purpose and goals. However, in this case, I decided not to apply parallel snowball networks and quota sampling due to the study's qualitative approach, scope and target group.

The study I present here is based on data from interviews with five young women and five young men with physical impairments. I conducted the interviews between March and October 2012. I have given all the participants fictitious names: Daniel 16 years, Peter 22 years, Axel 16 years, Elina 19 years, Kent 17 years, Lisa 28 years, Maja 19 years, Moa 29 years, Stefan 21 years and Vilma 20 years. All the respondents had congenital impairments and they were wholly or partly dependent on a manual wheelchair or a power chair. They came from Swedish middle-class families and had rich experiences of sport at different levels and from both schools and club activities. They had been involved in 
both team sports and individual sports since childhood and had parents and siblings who had experiences from different sports. In that sense, they all had been raised in sports families. At the time of the interviews, the majority were still taking part in sport, but three (one man and two women) had quit for various reasons. Direct quotations from interviewees (identified with pseudonyms) are used to illustrate the various themes and concepts from interviews.

\subsection{Ethical Considerations}

The research presented in this study has been organised to conform to the requirements of Vetenskapsrådets regler och riktlinjer för forskning (The Swedish Research Council. Rules and Guidelines for Research) (2006). The guidelines are not intended to replace the researcher's own appraisal or responsibility but rather to serve as the basis of the researcher's reflections and insights into his or her responsibilities. In addition, an ongoing discussion with research colleagues about ethical adjustments has taken place throughout the entire research process. In regard to the The Swedish Research Council. Rules and Guidelines for Research (2006), the fundamental individual protection requirements have been concretised into four general primary requirements for research, namely the information, approval, confidentiality, and the right of use requirements.

I informed the participants about the study and my institutional connection. Further, I gave them information making it clear that the results would be presented in research articles. I ensured that the participants knew they were free to terminate an interview at any time without having to provide a reason for doing so. Additionally, I personally conducted all the interviews, recorded the responses using a digital-recorder, and transcribed the interviews. At the end of each interview, the interviewee was allowed to add anything he or she believed to be of importance. When all interviews were conducted, I transcribed the data and anonymised the participant, removing all identifying information except for gender and age. After completing the transcription, I gave the interviewees the opportunity to review the transcripts and make corrections or additions. No data were changed or retracted as a result. These procedures are accepted among qualitative researchers (Gratton \& Jones, 2010; Kvale, 1996). The participants' real names have not been used in this study in order to avoid the risk of inadvertent disclosure of identities. However, this was a small group of young people with disabilities all living in the same city; as such, they are in a vulnerable position. In particular, the risk of internal identification was taken into consideration. In a few cases, I removed information from transcripts, such as when the interviewees had given information about another person involved in the study that may be readily identifiable to others. I re- moved this information to avoid the risk of harm or distress to the participants. These considerations have been balanced against the fact that the interviews were opportunities for the interviewees to verbalise their experiences and make their voices heard.

\subsection{Data Analysis}

Data were analysed using thematic content analysis. In the analysis process, we as researchers, moved between discrete entries in transcripts, whole transcripts, and across the different transcripts. Analysis began with specific observations progressing towards the emergence of a general pattern (Patton, 2002). The unit of analysis was primarily the complete experiences, ranging from one word to several sentences. Unique experiences in the data were coded and then rebuilt into larger interpretive themes (Patton, 2002). The themes were developed from the data and generated from relevant literature external to the study. In short, findings emerged out of the data through our interactions with the data. We intended to identify core consistencies and meanings in the qualitative material by reading and re-reading the text and by asking which themes were predominant.

\section{Results}

Based on the content analysis, I have constructed themes for presenting the results as follows: 1) Establishing oneself in sport, 2) Self-perceptions, 3) Sport on unequal terms, and 4) Limited by others.

\subsection{Establishing Oneself in Sport}

Learning is not something that only occurs in defined learning episodes, such as in PEH at school or in being taught how to do a specific sporting exercise in the local sport club. Instead, meaningful learning, is an unavoidable part of social life and participation in practice and transformative. It involves learning "how to do" practices through participating in them (Light, 2010). From this perspective, young men and women with disabilities participating in sport learn far more than just the sport specific techniques. They also gain a range of deep, implicit, social, cultural, and personal experiences that challenge their self- esteem and their understanding of themselves according to dominating gender norms (Butler, 1990; Oakley, 1972). Under the first theme, examples are given of how the male and female interviewees came into contact with organised sport along with what made them stay or what made them quit. Peter, Axel and Daniel come from families where sport is important. As shown by the quotations below, the parents' support and engagement were their chief reasons for practising sport:

Very much because of my mother. She was very anx- 
ious that her children should be doing some sport....If she couldn't drive me herself, she made sure that I arrived in some other way and so on. And missing a training session - that was out of the question. And I'm happy about that because I've always liked practising sport, so I'm glad that she pushed me on so that I really took part every time. (Peter 22 years)

Axel trained in different activities seven days a week. He said that he practised to feel fit and to meet his friends. Like Peter, it was his mother that made him start training:

It was thanks to my mother that I began doing the sport itself with floorball eight years ago....She took care of it and, well, she rang my previous coach and said "Hello, my son wants to start training", and then I could come and check it out, though I didn't want [to] but she just pressed on. And then, after a training session, I said that I didn't want to, but then she said, "Give it five training sessions", and after that, I have just continued. (Axel 16 years)

Daniel' father has been important to him. It was he who encouraged Daniel to start training and who has been there on the way though his sport. Daniel said that earlier on he had to commute to a bigger town to be able to play floorball. In order to make it possible for him to avoid long journeys, his father organised a team in his hometown and took on the task of coaching:

My dad has always believed in me and wanted me be a member of the national team, and he has also always fought for me to be able to take part. For when national team coaches have called and asked, people involved in the national team, what it's been like in our training sessions, he has always boosted me. (Daniel 16 years)

Four of the five interviewed women had positive experiences with sport, but their stories were not as equally natural as the men's. This gives the impression that it has not always been self-evident for the women to establish themselves in the space of sport. Elina has a motor disorder causing her to have to use her wheelchair only partially. At the time of the interview, she was not practising any sport:

Well, I've done swimming for several years, but I don't swim now. I've stopped. But I love playing wheelchair basketball. It's one of the most fun things I know. I love sport. Very much! (Elina 19 years)

I asked her why she stopped doing sport, and she answered:

I probably was and, still am, tired of it. But I'm thinking of taking it up again. Because it's like this when you've stopped for a rather long time, then it's rather difficult to start again. (Elina 19 years)

Moa, who no longer practised sport nor planned to start again, said that all physical activity during her childhood and adolescence was justified by a habilitation purpose. Experiencing social fellowship in sports contexts or choosing an activity based on what seemed interesting and fun never came into question. Joy and physical activity were incompatible things to her; everything was more or less "physiotherapy". She said that she quickly learned to adapt to the adults' will without questioning or initiating her own suggestions, which had a negative effect on her self-esteem. She expressed that she was so demanding on herself that sport did not suit her. In addition to her motor disorder, Moa also has a visual impairment that makes her almost totally blind, which has made it even more difficult to find social contexts where she could share her experiences with others who have similar preconditions and experiences. She explained:

I started doing water training when I was five years old and riding when I was two years old, but then there were two people who had to hold me so that I stayed on the horse's back. There was nobody who pepped me up; it was just a matter of course that I should do it until I sort of cracked up when I was $14 . .$. it was physiotherapy, and that was that. Then I started doing group training; it was probably the first time I really made a choice myself. It was fun as long as I saw myself as a beginner, but then when the demands increase, I began thinking of what I achieved, or perhaps mostly what I didn't achieve. Then I quit because I always felt that I was a failure. (Moa 29 years)

According to the interviews, it is clear that the men have had greater support from parents, teachers and trainers in their sporting activities than the women had. The results also indicate that they are more likely than their female counterparts to perceive and understand sport as a natural ingredient in their lives both during childhood and in current life. The women's stories reveal a major doubt and struggle for a place in sport. This can be linked to gender and ability norms that are culturally and socially constructed to support heterosexual masculinities (Butler, 1990; Oakley, 1972). All the interviewees quoted above started doing sport when they were relatively young. When Peter, Axel and Daniel described how it happened and on whose initiative, it was obvious that the parents were important. The results thereby support the research that has shown that it is most often adults close to the child who express and protect the child's needs (Fitzgerald et al., 2003). Moa's story is, however, an exam- 
ple of negative discrimination and of how such inadequate treatment and lack of understanding of the child's needs result in crushed self-esteem (Blinde \& McCallister, 1998; Goodwin \& Watkinson, 2000).

\subsection{Self-Perceptions}

The golden $\mathrm{M}$ is a universal symbol. Wherever we go in the world, we know that the rounded yellow letter symbolises McDonald's. It is not necessary to be a devoted fast food freak in order to imagine at first sight of the $M$ what the restaurant's interior fittings look like, what is included on the menu and how the burgers taste. Correspondingly, the wheelchair is a universal symbol of disability and of what the person sitting in the wheelchair can manage, or perhaps cannot manage. It is therefore inevitable for a person who has a disability and uses a wheelchair to relate to other people's and her/his own conceptions of the wheelchair's symbolic value. This section demonstrates the interviewees' experiences of the body, their physical and psychological development, and their capability in accordance to dominating notions of ability. Developing implies discovery of both one's potentials and one's limits. The interviewees expressed in different ways that sport sometimes made them painfully aware of the limitation that disability implies with regard to participation and independence. Through challenges in sports contexts, they have experienced what they can do, what is possible and what is impossible and what can be done in a different way or with the aid of support.

Stefan gave examples of the self-perception he gained by being confronted with his potential and limits and by his journey there, which was not completely painless:

And I know that disabled people will hate me for saying this because some disabled people want to believe [that] we are just like all other people, but my philosophy is roughly like this: "But if you are just like all other people, why don't you stand up and walk?"...I mean, what I try to teach in boxing is what I experience that many disabled people lack; that even if it's difficult to accept one's impairment-for I think that it is myself, very difficult; I mean I was forced to realise when I was 16 years old that I could no longer brush my teeth because I missed so much that I could get holes in them. That was really difficult, but I realised that I had to get help to brush my teeth; otherwise, I would get holes, and that would cause terrible problems. It's the same way with the training and everything else in life: realise your limits so that you can function as well as possible on that basis. (Stefan 21 years)

Like Stefan, Vilma has also challenged herself in various sports contexts. Her experiences have given her valuable self-perception and influenced her self-esteem:
I know that I'm actually not exactly like all other people. I cannot do exactly the same things as all others....and I have been feeling lately that it has had a negative effect on my self-esteem. Because since I have so many ambulatory friends, I try to keep up with everything they do, but sometimes I have to do things in a completely different way and that can, of course, many times be difficult. But l've probably felt that I want to try to find myself: who am I? But also that I cannot play the part of someone who is not me because that can also be rather difficult. (Vilma 20 years)

When I asked them if they had any strong positive experience of a sports context where they had been acknowledged and would like to describe, Peter gave the following answer:

I had been doing airgun shooting for a couple of months, and my paternal uncle who shoots on the national team was going to take me with him to the shooting range and I would be able to try shooting with his gunpowder weapon because I was going to start shooting with gunpowder at the time. I would be allowed to shoot, and he would stand beside me and sort of teach me some tips and tricks. I shot five shots. He goes and fetches the target, looks at it and then says, "I've got nothing to teach you!" (he laughs). (Peter 22 years)

This experience confirmed Peter and his ability to perform. Lisa described when she was acknowledged in connection with a floorball match and how important this was for her self-esteem:

One thing that I remember even today...it's one of the last floorball matches we took part in, and I was appointed the player of the team that day. And also that our coach asked, "Where the hell have you been all my life?" I thought that was a great moment. From being hardly noticed on the floor to being appointed the player of the team, that's a very great step because I never really managed to score a goal and things like that. (Lisa 28 years)

At the time of the interview, Stefan had experienced a relatively severe cereberal palsy and used a motor chair in his everyday life and in connection with training. He trained boxing seven days a week and also worked as a coach for both people with motor disorders and ambulatory participants in a boxing club in the town where he lived. He said that the training radically changed his life:

And just one thing is that I can now sit up. I couldn't sit up very well before. I had to have one of those four-point belts, one of those that cover the whole 
chest. And I still sat askew, although it was fastened, like. And another thing, my hands were very much askew and pointed inwards.... Now they are out here [he shows his hands]. And before I couldn't even hold a glass without dropping it because my hands were shaking like hell. Now I can hold a glass with one hand if I want to. So, I think I have made several advances. (Stefan 21 years)

Kent felt that sport helped him to dare to test his limits. It helped him to gain stronger self-confidence. He stated that he knew what he could manage on his own and what he must ask people close to him to help him with, both in the sport context and in other situations in life:

The fact that I feel secure and test all limits, I think that is because I'm engaged in sport, actually during my whole childhood and adolescence. Because then I know I can drive that fast, I can move that much, I can do that much. (Kent 17 years)

The above quotations indicate that some of the interviewees had very positive experiences of sport. Being physically strong increases the chances of attaining autonomy and independence. Challenging oneself in various sports contexts also seems to increase one's selfconfidence and self-knowledge, which gives inner security. Like this study, previous research has shown that children and young people with disabilities have positive experiences of sport in contexts where they are fully included and can develop their physical, mental and social skills (c.f., Kristén et al., 2002). As Hargreaves (2000) argued, sport is one of the few institutions in society where women and men with disabilities can change themselves to become more independent and autonomous. The above quotations might hence be interpreted as if sport contributes to strengthening the individual's experience of capability in relation to normative conceptions of sport and the body. However, corresponding experiences were not found among the female interviewees. This finding can be interpreted to mean that disabled men seek to demonstrate physical prowess, power and mastery over their own bodies through their sport participation (c.f., Huang \& Brittain, 2006; Messner, 1992) and that this construction of the self can be linked to the gender (Butler, 1990; Oakley, 1972) and ability norms (Garland-Thomson, 1997; Seymour, 1998).

\subsection{Sport on Unequal Terms}

This section tells participants' experiences in school subject PEH. Peter was critical. During his upper secondary years, he had PEH in a group consisting only of students with motor disorders. He said that he is competitive that he was not given any challenges and that most activities were playful. He said that on several occasions he tried to make the teachers agree to spend one or a few lessons on the ice-skating rink so that he and the other students would be able to try out sledge hockey, but that this did not lead to any result:

Now I have a mark in sport that I don't think I have deserved since I feel that I have not been challenged at all. (Peter 22 years)

We continued our talk and discussed the importance of different policy documents that regulate sport and the possibility of influence. Peter then answered:

Well, if you can make it work, it's very good. But it is precisely that, to make people follow it....Because then you get away from the feeling I have, that I have a mark in sport that I haven't deserved at all.... The last year I refused to take part every time they played tag, which was most of the time, and I've still got a Pass with Distinction. If you refuse to take part in nine out of ten lessons, you shouldn't get a mark. You know, you start doubting yourself and what you've really achieved in all the subjects you've got marks in. (Peter 22 years)

Why did Peter get a pass with distinction? What were the teachers aims with this? Probably it wasn't their aim to undermine his confidence, probably completely the opposite, but nevertheless he started doubting his abilities in all subjects because he received a grade he felt he didn't deserve. Just like Peter, several of the interviewees stated that they had difficulties in voicing their opinions on the subject of PEH at school and that the teachers neglected their interests, views and preconditions. Vilma put it like this:

In lower secondary school, I was not allowed to take part, or my teachers...she said to me that I couldn't be together with the class because I sat on a wheelchair and then she wouldn't be able to give me a mark.... I was very, very disappointed because I felt that I wanted to be with [the] class, and she said that I could have PEH alone with her. Then I said that that wouldn't develop me at all. So we mailed her and my mother called her. I could have like two lessons alone with her and I thought it was terribly dull, but then I also said, "Please, can't I get a chance to prove who I am?" You don't even know for 100 per cent who I am. It feels as if you are discriminating against me". Then I was allowed to be together with the class and in the end I got a Pass with Distinction as my mark. (Vilma 20 years)

Sports days are a further example of sports contexts where the interviewees experienced isolation. Maja, who attended an ordinary class in lower and upper secondary school but in a group with only students with motor disorders in the physical education lessons, 
had the following experiences:

In lower and upper primary school, I was nearly always at home on sports days. I thought it was very sad because I wanted to be with the others....My friends asked me where I was, but then I had to say that they hadn't arranged anything for me. But in lower and upper secondary school, I took part in the sports days because then I was in a wheelchair class. It was not until then that they [the teachers] cared about it and that I felt I was secure. (Maja 19 years)

Several of the interviewees stated that they had negative experiences of the subject of PEH and that they had been exposed to both open and hidden discrimination (c.f., Husu, 2005). They felt that it was more or less up to the students themselves to find solutions to what was considered a problem, namely the students' inadequate preconditions for taking part in ordinary lessons. The above quotations also visualise how they experienced that the teacher looked upon them and treated them differently in relation to their classmates. The interviewees also said that they felt insecure in connection with the subject of $\mathrm{PEH}$, since they seldom knew in advance what would happen, how the lesson was organised and if they could participate under the same conditions as their classmates. It is possible that the interviewees regarded organised sport as more accessible and positive than the teaching of PEH offered by schools or that they expected that education, which is compulsory, would offer greater opportunities for co-determination, influence and individual development than organised sport. Another conceivable explanation might be that the interviewees had not wanted to be separated from their classmates and that in contexts where this happened they experienced direct isolation. Some interviewees stated that exclusion in connection with the PEH lessons further strengthened the experience of being different. It is also one reason why several of them during their school years chose, to the extent that it was possible, to have PEH in a special group with only students with motor disorders. As research has shown, children and young people develop an early awareness of what bodies are regarded as "capable in sport", which has consequences for how they conceive of and understand themselves and each other in relation to the practice of sport, as illustrated by the above quotations (Redelius et al., 2009). The negative experiences of $\mathrm{PEH}$ do not seem to have impacted on the interviewees' willingness to participate in sports and leisure. This is possibly explained by the fact that all of them came from social contexts in which sport has played a central and important role in every-day life.

\subsection{Limited by Others}

This section shows that the interviewees had challeng- es in regard to sport participation. Some of the factors that they mentioned as obstacles to their opportunities for doing sport included the need for assistance, home care and subsidised transportation service for the disabled. Daniel travelled together with his coach to and from the wheelchair floorball, and that arrangement worked well for him because he did not have to think about booking transportation service or catching the local buses, which would be time-consuming for him, since he lived on the outskirts of the town. For the interviewees who lived in boarding houses or in special dwellings, they must adapt their leisure time to some extent to the staff's working timetable. Daniel said:

It's very difficult. When I've been training and things like that, I have to rush home so that it will work for them [the staff]. For this reason, I've been at home quite a lot only to make it work for them. (Daniel 16 years)

Peter's situation resembled Daniel's. He said that he has tried out most sports and that sport means a lot to him, above all the social fellowship and the possibility to discuss things that affect his existence together with people who also have disabilities. At the time of the interview, he was not engaged in any sport primarily because it was difficult for him to leave his home. He lived in a flat of his own, but he was in need of home care. In his narrative, it became obvious that his home was not only a place for freedom, recreation and rest but also a place of work for home care and assistance companies, for which reason his leisure-time must be weighed against his need for help.

The way things are now, it's very difficult to have staff coming home and working at my place. So I'm often stuck at home. It's not very often that I go away to do things....It's the home care, so it's not possible for them to meet me somewhere else to help me. So I have to be at home when they come, and they come very often. (Peter 22 years)

Axel's parents drove him to and from the training when he was younger and lived at home. At the time of the interview, he had moved to a bigger town, attended upper secondary school and stayed at a boarding house, traveling to and from the training sessions by himself. To get to boxing and athletics, he used his manual wheelchair, but getting to floorball required using a transportation service. Many of the interviewees have experienced problems with the transportation service. Since the transportation service must be booked ahead of time, it is difficult to take part in activities spontaneously. Although the taxi was always booked in advance, they often had to wait for a long time, and several of the interviewees experienced worry and stress about never being quite certain that the taxi would arrive at the time 
agreed on. Most of them had sometimes been badly treated by taxi drivers in connection with transportation service journeys. It is a difficult situation to be alone many times in a limited space together with a person they do not know and are dependent on:

Well, it's always that they arrive too late and that they can't find the way...those are probably the most usual things. But sometimes they have also been unpleasant. It was perhaps a few years ago, it was a taxi driver who got bloody angry because...I don't quite know what happened, but in the end he was so pissed off that he threw the wheelchair.... When I calmed down, I talked to the police because such things shouldn't happen. But if the wheelchair had broken, I had nothing else. I would have had to creep or something; it wouldn't have worked. (Kent 17 years)

Previous research has pointed out that children and young people with disabilities are excluded from sport due to factors that can be related to the disability in itself and to the need for help and support that it implies (Taub \& Greer, 2000; Vickerman et al., 2003). As the interviewees confirmed, the time required for treatment and care and transportation difficulties are real obstacles to taking part in sport. Their experiences thereby show that there are a number of surrounding factors that cannot be directly connected with sport but still have consequences for the individual's opportunities to participate. There are of course a number of factors that facilitate or prevent participation for children in general regardless of disability, but the above quotations confirm what previous research has shown, namely that there are conditions that are specific for children and young people with disabilities.

\section{Conclusions}

In this paper, my intention was to examine how young people with disabilities made sense of sport, within both the compulsory school system and the voluntary sports movement. The small sample was not representative but rather, provided valuable insights into one particular social, disability and sports context. On the whole, the interviewees have had good experiences of sports within the voluntary sports movement and confirmed that, in many ways, it has been and continues to be an important part of their lives. Their experiences indicate that those who have gone on doing sport began early in life. With the support of adults, they have overcome many of the barriers described by previous research. The factors that encouraged the majority of them to stay in sport are the social environment, the chance of greater autonomy, the independence that the training has contributed to, and the acknowledgement they have been given in various ways through feeling capable in a sports context. Those who have quit or taken a break from sport stated in all cases but one that they had done so for reasons that could not be directly attributed to faults and shortcomings in sport. Such examples are difficulties in solving the logistics of home care, assistance companies or transportation services or that the practice of sport has been incompatible with a demanding school situation. A break from sport does not therefore always have to be a direct consequence of qualitatively inferior or unsatisfactory activities. On the other hand, the interviewees themselves are a product of the sports practice and its prevailing norms and ideals.

A general pattern in the interviewees' experiences is that all of them, to a varying degree, had been dissatisfied with the teaching of the school subject of PEH. Above all, their dissatisfaction arose from the teacher's deficient ability to adapt the teaching to the student's needs. The interviewees were excluded from the teaching, experienced insufficient opportunities for participation and co-determination or thought that the teaching lacked challenges and was too playful. In their opinion, the teacher's expectations of the student's sports performance were unclear, which is perhaps the most remarkable aspect. The deficiencies of the education may, on the other hand, have structural causes and be a matter of, for example, resources, time and working conditions. This result raises questions about the training the teachers themselves received. Are their actions a failure of their own abilities or a failing of the training system they went through to become teachers? Since this wasn't the focus of this study I cannot give a clear answer on this question.

All in all, the challenges in sport have for most of the interviewees led to strengthened self-perception. The experiences that emerged in the interviews indicate that it is important that children and young people with disabilities are given opportunities to explore their limits and potentials but also that they are acknowledged for their sports achievements. However, to a degree this is also true of non-disabled children in sport in that the activity allows them to explore their own physical boundaries at that point in their development and in relation to their peers. Openness and dialogue between performers, leaders and parents are prerequisites for the functioning of sport in practice. As the interviews showed, several of the participants were satisfied with their practice of sport, which indicates that there are environments where words are actually turned into action.

\section{Acknowledgements}

An earlier version of this paper was presented at the 11th Annual Conference of the European Association for Sociology of Sport (EASS), Utrecht (Netherlands): Changing Landscapes in Sport: Dynamics, hybridities and resistance, May 7-10, 2014. This study is partly associated with an interdisciplinary project headed by 
Prof. Lotta Vikström, "Experiences of disabilities in life and on line: Life course perspectives on disabled people from past society to present", which the Wallenberg Foundation (Stiftelsen Marcus och Amalia Wallenbergs Minnesfond) recently funded with 5 million SEK (July 2014). The author gratefully acknowledge the anonymous referees whose careful response on this paper has improved it dramatically.

\section{Conflict of Interests}

The author declares no conflict of interests.

\section{References}

Blinde, E., \& McCallister, S. (1998). Listening to the voices of students with physical disabilities. Journal of Physical Education, Recreation and Dance, 69(6), 64-68.

Butler, J. (1990). Gender trouble: Feminism and the subversion of identity. New York: Routledge.

Carlsson, B., \& Fransson, K. (2005). Official sports poli$c y$, and children's rights in society. Retrieved from http://idrottsforum.org/articles/carlsson/carlsson_f ransson/carlsson_fransson051130.html

Clark, S. (2012). Being "good at sport": Talent, ability and young women's sporting participation. Sociology, 46, 1178-1193.

Coates, J., \& Vickerman, P. (2010). Empowering children with special educational needs to speak up: Experiences of inclusive physical education. Disability and Rehabilitation, 32(18), 1517-1526.

Cohen, N., \& Arieli, T. (2011). Field research in conflict environments: Methodological challenges and snowball sampling. Journal of Peace Research, 48(4), 423-435.

Cole, C. (1994). Resisting the canon: Feminist cultural studies, sport, and technologies of the body. In S. Birrell \& C. Cole (Eds.), Women, sport and culture. Champaign IL: Human Kinetics.

Denzin, N. K., \& Lincoln, Y. S. (Eds.). (2008). Strategies of qualitative inquiry. Thousand Oaks, CA: Sage.

DePauw, K. P. (1997). The (in)visibility of disability: Cultural contexts and "sporting bodies". Quest, 49(4), 416-430.

Education Act. (1985). Sweden: Ministry of Education and Science in Sweden.

Evans, J., Rich, E., Allwood, R., \& Davies, B. (2007). Being "able" in a performative culture: Physical education's contribution to a healthy interest in sport? In I. Wellard (Ed.), Rethinking gender and youth sport (pp. 51-67). London: Routledge.

Fitzgerald, H. (2005). Still feeling like a spare piece of luggage? Embodied experiences of (dis)ability in physical education and school sport. Physical Education \& Sport Pedagogy, 10(1), 95-108.

Fitzgerald, H., Jobling, A., \& Kirk, D. (2003). Listening to the "voices" of students with severe learning diffi- culties through a task-based approach to research and learning in physical education. Support for Learning, 18(3), 123-129.

Garland-Thomson, R. M (1997). Extraordinary bodies. Figuring physical disability in American culture and literature. New York: Columbia University Press.

Goodwin, L., \& Watkinson, J. (2000). Inclusive physical education from the perspectives of students with physical disabilities. Adapted Physical Activity Quarterly, 17, 144-160.

Gratton, C., \& Jones, I. (2010). Research methods for sport studies. London: Routledge.

Hargreaves, J. (2000). Heroines of sport. The politics of difference and identity. London: Routledge.

Huang, C.-J., Brittain, I. (2006). Negotiating identities through disability sport. Sociology of Sport Journal, 23(4), 352-375.

Husu, L. (2005). Dold könsdiskriminering på akademiska arenor-Osynligt, synligt, subtilt. [Covert gender discrimination in academic arenas-Invisible, visible, subtly]. Stockholm: Högskoleverket.

Karlefors, I. (2012). There are some things we learned-that we hadn't thought of: Experience of and learning in the subject of physical education and health from a student perspective. Swedish Journal of Sport Research, 1, 59-82.

Kaplan, C., Korf, D., \& Sterk, C. (1987). Temporal and social contexts of heroine-Using populations: An illustration of the snowball sampling technique. Journal of Mental and Nervous Disorders, 175(9), 566-574.

Kristén, L., Patriksson, G., \& Fridlund, B. (2002). Conceptions of children and adolescents with physical disabilities about their participation in a sports programme. European Physical Education Review, 8(2), 139-156.

Kvale, S. (1996). Interviews. An introduction to qualitative research interviewing. London: Sage Publications.

Kvale, S., \& Brinkmann, S. (2009). Interviews: Learning the craft of qualitative research interviewing. Thousand Oaks, CA: Sage Publications.

Larsson, H. (2004). Vad lär man sig på gympan? Elevers syn på idrott och hälsa i år 5 [What do you learn in physical education? Pupils' view of physical education and health in grade 5]. In H. Larsson \& K. Redelius (Eds.), Mellan nytta och nöje: Bilder av ämnet idrott och hälsa. [Between business and pleasure: Images of physical education and health]. (pp. 123148). Stockholm: Idrottshögskolan.

Light, R.L. (2010). Children's social and personal development through sport: A case study of an Australian Swimming Club. Journal of Sport and Social Issues, 34(4), 379-395.

Maxwell, G., \& Granlund, M. (2011). How are conditions for participation expressed in education policy documents? A review of documents in Scotland and Sweden. European Journal of Special Needs Education, 26(2), 251-272.

Messner, M. A. (1992). Power at play: Sports and the 
problem of masculinity. Boston, MA: Beacon.

Nilholm, C. (2006). Special education, inclusion and democracy. European Journal of Special Needs Education, 21(4), 431-445.

Oakley, A. (1972). Sex, gender and society. London: Temple Smith.

Olofsson, E. (2007). The Swedish sports movement and the PE teacher 1940-2003: From supporter to challenger. Scandinavian Journal of Educational Research, 5(12), 163-183.

Patton, M. Q. (2002). Qualitative research methods and evaluation methods. Thousand Oaks, CA: Sage.

Peterson, T. (2005). När fälten korsas [When the fields are crossed]. Svensk Idrottsforskning, 14(3), 9-11.

Redelius, K., Fagrell, B., \& Larsson, H. (2009). Symbolic capital in physical education and health: To be, to do or to know? That is the gendered question. Sport, Education and Society, 14(2), 245-260.

Ritchie, J., \& Lewis, J. (2003). Qualitative research practice: A guide for social science students and researchers. Sage: London.

Riksidrottsförbundet. (2009). Idrotten vill [What sports wants]. Stockholm: Riksidrottsförbundet.

Rowe, D. (1998). Play up: Rethinking power and resistance. Journal of Sport and Social Issues, 22(3), 241-251.

Schell, L. A. B., \& Rodriguez, S. (2001). Subverting bodies/ambivalent representations: Media analysis of paralympian, Hope Lewellen. Sociology of Sport Journal, 18(1), 127-135.

Seymour, W. (1998). Remaking the body. Rehabilitation and change. St Leonards NSW: Allen \& Unwin.

Shilling, C. (2004). Physical capital and situated action: A new direction for corporeal sociology. British Journal of Sociology of Education, 25(4), 473-487.

Smith, A., \& Thomas, N. (2006). Including pupils with special education needs and disabilities in national curriculum physical education: A brief review. European Journal of Special Needs Education, 21(1), 69-83.

Spaaij, R., Farquharson, K., Magee, J., Jeanes, R., Lusher, D., \& Gorman, S. (2014). Journal of Sport \& Social Issues, 38(4), 346-365.

Taub, D. E., \& Greer, K. R. (2000). Physical activity as a normalizing experience for school-age children with physical disabilities. Journal of Sport and Social Is- sues, 24(4), 395-414.

Trondman, M. (2011). Ett idrottspolitiskt dilemma. Unga, föreningsidrotten och delaktigheten. [A Sport political dilemma. Young, club sports and participation]. Sweeden: Centrum för idrottsforskning.

Unicef. (2008). Handbok om barnkonventionen [Implementation handbook for the convention on the rights of the child]. Stockholm: Unicef.

Vetenskapsrådet. (2006). Regler och riktlinjer för forskning. Humanistisk och samhällsvetenskaplig forskning [The Swedish Research Council. Rules and guidelines for research. The humanities and social sciences]. Retrieved from http://www.codex.vr.se/co dex_eng/codex/oversikter/humsam/humsam.html

Vickerman, P., Hayes, S., \& Whetherly, A. (2003). Special educational needs and national curriculum physical education. In S. Hayes \& G. Stidder (Eds.), Equity in physical education (pp. 47-65). London: Routledge.

Wickman, K., 2008. "I do not compete in disability": How wheelchair racers challenge the discourse of ableism through action and resistance. European journal for sport and society, 4(2), 151-167.

Wickman, K. (2011a). Flickor och pojkar med funktionsnedsättning och deras rättigheter och möjligheter till ett aktivt idrottsliv. [Girls and boys with disabilities and their rights and opportunities for an active sporting life]. In Norberg \& Pihlblad (Eds.), För barnets bästa: En antologi om idrott ur ett barnrättsperspektiv. [For the child's best: An anthology of sports from a child rights perspective]. Stockholm: Centrum för idrottsforskning.

Wickman, K. (2011b). The governance of sport, gender and (dis)ability. International Journal of Sport Policy, 3(3), 385-399.

Özdemir, M., \& Stattin, H. (2012). Konsekvenser av att börja, fortsätta eller sluta idrotta. En longitudinell studie av ungdomars psykologiska och beteendemässiga anpassning [Consequences of start, continue or stop playing sports. A longitudinal study of young people's psychological and behavioral adaptation]. In J. Hvenmark (Ed.), Är idrott nyttigt? En antologi om idrott och samhällsnytta. [Is sport healthy? An anthology of sports and community benefit] (pp. 112-135). Stockholm: SISU idrottsböcker.

\section{About the Author}

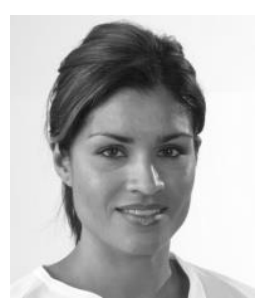

\section{Dr. Kim Wickman}

Kim Wickman is a Senior Lecturer and Researcher at the Department of Education, Umeå University. $\mathrm{Kim}$ is teaching in courses related to gender, diversity and sport mainly in the Special Needs, Sport Science and Physical Education and Health Programmes. She has research interests in sport, gender and disability. 